\title{
The Impacts of Building Regulations on the Thermal Performance and Energy Consumption of Residential Buildings in Riyadh City-Saudi Arabia
}

\author{
Saleh Baharetha, Elsayed Amer, Mohammad Kotbi \\ Department of Architecture and Building Sciences, College of Architecture \& Planning, King Saud University, \\ Riyadh, Saudi Arabia \\ Email: saleh1882@gmail.com, eamer@ksu.edu.sa, mkotbi@ksu.edu.sa
}

How to cite this paper: Baharetha, S., Amer, E. and Kotbi, M. (2021) The Impacts of Building Regulations on the Thermal Performance and Energy Consumption of Residential Buildings in Riyadh City-Saudi Arabia. Open Journal of Energy Efficiency, 10, $1-21$.

https://doi.org/10.4236/ojee.2021.101001

Received: January 22, 2021

Accepted: March 14, 2021

Published: March 17, 2021

Copyright $\odot 2021$ by author(s) and Scientific Research Publishing Inc. This work is licensed under the Creative Commons Attribution International License (CC BY 4.0)

http://creativecommons.org/licenses/by/4.0/

\begin{abstract}
Riyadh city is the fastest growing city in Saudi Arabia. The rapid urban growth that happened recently in Riyadh was not based on the traditional urban planning principles, which have been established and applied for the city development process. The imported building regulations have created a new urban structures and street patterns. The contemporary urban form in Riyadh city is based mainly on traffic and economic consideration with the neglect of environmental dimensions. This research aims to examine the impacts of building regulations on the thermal performance of residential buildings in Riyadh city, with the ultimate goal of establishing planning guidelines that consider the environmental conditions of the city. The methodology adopted for achieving the aim of this study consists of two phases. First, the literature related to building regulations development in Riyadh, as of 2018, was reviewed. Second, buildings energy simulation was conducted to examine the thermal performance of the typical current status of residential building blocks in Riyadh city, and then several changes to building regulations were made to investigate their impacts on the thermal performance of buildings. The results showed that the impacts of Riyadh building regulations on the thermal performance of residential buildings differ across the evaluated cases. The ratio of building height to street width, urban block street orientation, and building orientation are the main factors affecting thermal performance of buildings within urban block. The study also concludes that adjusting the ratio of building height to the distance between buildings could have a significant impact in reducing cooling loads. This study will help policy makers, planners and designers to investigate the shortcoming in the current building regulations.
\end{abstract}




\section{Keywords}

Building Regulations, Energy Consumption, Thermal Performance, Residential Buildings

\section{Introduction}

Global warming and climate change anthropogenic greenhouse emission, made it mandatory to make immediate initiatives to avoid sever consequences for future generations. Buildings are responsible for releasing $50 \%$ of the atmosphere emissions and $70 \%$ of sulphur dioxide into the atmosphere. They are also accounting for consuming $40 \%$ of the world energy and $40 \%$ of the total GHG emissions [1]. In response to these statistics, it became important to address energy consideration towards producing energy efficient buildings. Energy requirement is increasing in line with globalization and population growth, as a result, lots of efforts being made globally to conserve energy resources and optimize energy consumption [2].

In Saudi Arabia, electricity consumption has rabidly increased at a rate of 7\% [3] and the residential sector is responsible for consuming $50 \%$ of the total energy consumed by buildings [4] as shown in Figure 1. In addition, air conditioning systems consume over $70 \%$ of residential buildings' total energy consumption for the aim of improving indoor thermal comfort [5]. Due to the economic growth and increasing population, Saudi Arabia is experiencing a huge expansion in infrastructure, especially in residential buildings [6]. As a result, the energy demand in residential buildings is very high where about $70 \%$ of electricity is consumed by air conditioning systems due to the hot climate of Saudi Arabia [7].

As a part of the Paris agreement of climate change [8], Saudi Arabian Government considers that reducing energy consumption in buildings became a major topic for policy making process due to the increasing demand for fossil fuel. Several initiatives have been introduced to Saudi Arabia to reduce energy consumption in buildings. In particular, a part of the Vision 2030 of the Kingdom of Saudi Arabia is committed to reduce carbon emissions by 130 million tons by 2030 [3]. In addition, Saudi Energy Efficiency Centre (SEEC) has been

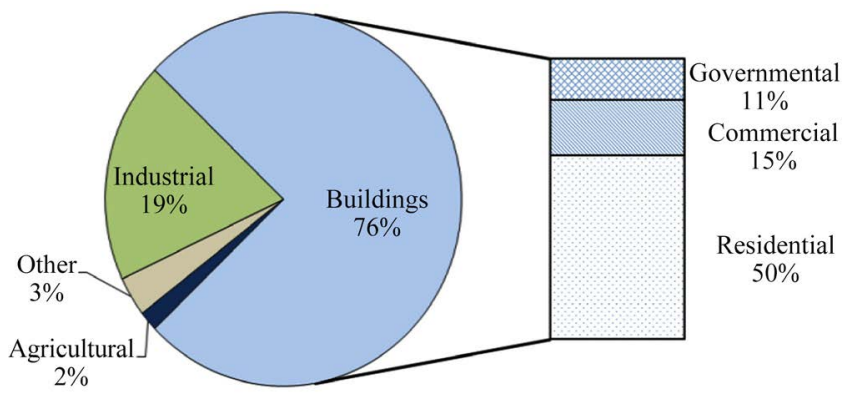

Figure 1. Total energy consumption per sector in Saudi Arabia in 2011 [4]. 
established in 2010 to reduce energy demand for all sectors including buildings through regulations, education and audits [9].

Furthermore, there is a dramatic increase in the population of Riyadh in the last decades, it has increased from an estimated of 14,000 in 1902 , to 666,480 in 1974, to reach more than 2.8 million in 1992, more than 4.8 million in 2004, 5.25 million in 2010 and to more than 6.5 million in 2016 [10]. Most recently, Riyadh population is nearly $8,276,700$ million [11].

Urban pattern, building orientation and shading are some of the traditional techniques used to reduce the impact of local climate and to improve the thermal comfort inside buildings in desert environments [12]. However, Modernization have resulted in replacing traditional urban pattern by western urban patterns, which requires immediate actions to avoid the increasing rates of energy demand. In order to achieve this, many efforts should be enforced by policy makers in Riyadh to introduce a compatible building regulation with such a hot arid climate. In this research, the impact of building regulations on the thermal performance of residential buildings is investigated for a base case residential building to assess the potential reducing in cooling loads.

\section{Overview of Building Regulations Development and Urban Growth in Riyadh}

Riyadh is located in the eastern part of the Arabian Peninsula, between latitudes $24^{\circ}$ and $28^{\circ} \mathrm{N}$ and longitudes $44^{\circ}$ and $48^{\circ} \mathrm{E}$, and approximately 600 metres above sea level. It has a hot arid climate with extreme difference in temperatures between summer and winter. The temperature ranges from $(33-45)^{\circ} \mathrm{C}$ in summer, and from $(0-20)^{\circ} \mathrm{C}$ in winter [13] and [14]. It was found over the ruins of several communities around 1740. In 1842, it became the capital of the second Saudi State, however it had a little prominence until King Abdul-Aziz took over in 1902 as independent governor and began his campaign for the consolidation of modern Saudi Arabia [15]. During its physical development process, major events took place in Riyadh, which are the planning and construction of: Al-Murabba, Nasriyah and Al-Malaz complexes [16]. During 1930s, the physical transformation took place in Riyadh when King Abdulaziz decided to build a large palace and administrative complex to the north of the city, known as Al-Murabba. The palace covers an area of $400 \times 400 \mathrm{~m}$ with a height of two and a half stories [17]. The general urban characteristics of Al-Murabba palace was very similar to the traditional urban plan found in Riyadh, it has narrow streets, adjacent building and courtyards as shown in Figure 2. The main difference between Al-Murabba palace and the traditional urban pattern of Riyadh was the huge scale of its building construction program [16].

Riyadh was affected by the huge scale of building program in two ways. First, a new system of transportation was introduced, where motor vehicle became the only modern transportation system used in Riyadh. Secondly, the size of Riyadh was stretched rapidly and its physical growth was defined [19]. According to 
[15], in 1953, Nasriyah was rebuilt and expanded by King Saud as his royal residence. It was planned according to a grid pattern with modern palaces in contrast to the traditional pattern of Riyadh, so it introduced an alternative way of planning by that time. Furthermore, it was built out of reinforced concrete and cement as opposed to traditional materials of clay, wood and mud [15]. In 1957, when the government decided to transfer agencies from Mecco to Riyadh, AlMalaz project "New Riyadh", was built $4.5 \mathrm{~km}$ northeast of the centre of the city to provide housing for the transferred government employees. It consists of about 754 detached dwelling units and three apartment buildings. The urban geometry of Al-Malaz has a gridiron plan with rectangle blocks and hierarchy of streets and large lots with square shape. The typical lot size was nearly $25 \times 25 \mathrm{~m}$ with a variety of widths within some blocks. New concepts of planning have been introduced to Al-Malaz housing projects, where the dwelling was introduced as a detached residential units and the street pattern was designed as a grid [19], as shown in Figure 3. The construction of Al-Malaz was accompanied by listing of written regulations which showed that the urban pattern reflects the first transformation of traditional Saudi built environment to contemporary environment [20].

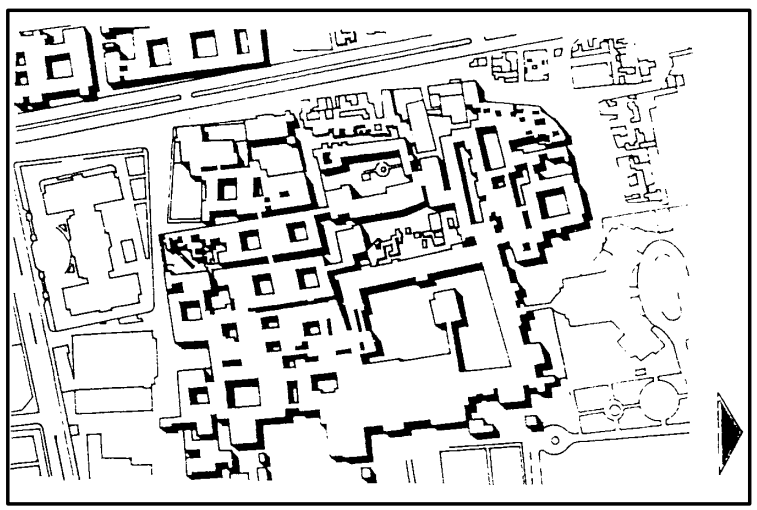

Figure 2. Riyadh-Al-Murabba: site plan [18].

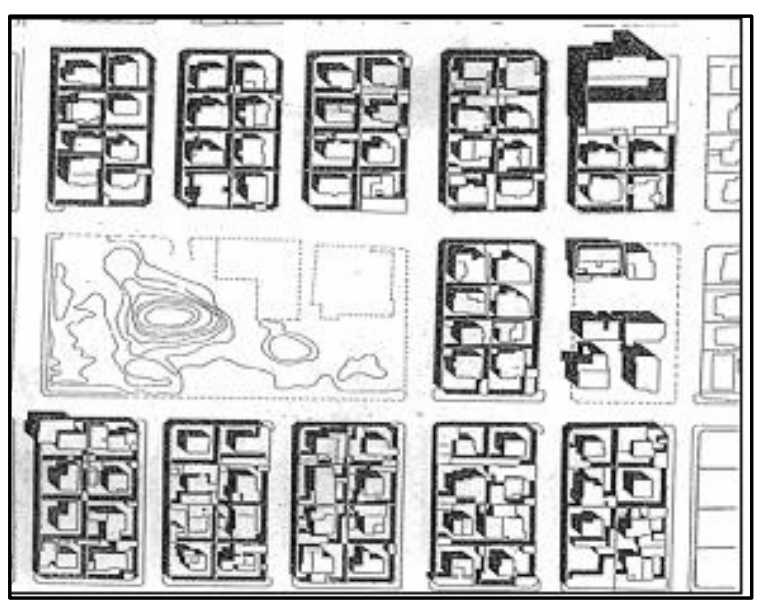

Figure 3. Al-Malaz neighbourhood, 1970's [20]. 
The development of zoning regulations in Saudi Arabia comprises three main phases. First, the development of regulations before 1930 when the first master plan of Riyadh was developed. Second, regulations and master plan of Riyadh developed by Doxiadis, which confirmed the setback requirement and the minimum lot size standards and accompanied by a documented guidelines and planning regulations. The third phase includes the development of zoning regulations which were modified by the new proposed master plan of Riyadh [16].

\section{Research Methodology}

This study aims to evaluate the impacts of building regulation on the thermal performance of residential housing in Riyadh with the ultimate goal of reducing energy consumption. There are three types of residential buildings in Riyadh: Villa (detached single unit), attached unites (duplexes) and apartments. According to Alaidroos and Krarti [21], detached single units in Riyadh represent approximately $40 \%$ of the existing residential buildings. Accordingly, reducing energy consumption of this type of residential buildings would contribute significantly in reducing the overall consumption of residential buildings in Riyadh and Saudi Arabia. Therefore, this study will focus on the building regulations of detached single units. As a common type, a base case study of two-story residential building in case of being free standing was modelled digitally to act as a reference building for this research. The energy behaviour for this building was simulated using DesignBuilder software and then compared with the thermal performance of the same building within several cases and geometries of urban block.

The DesignBuilder software was developed by DesignBuilder Software Ltd, United Kingdom. It is a popular software tool used for modelling and simulating energy efficiency in buildings [5]. DesignBuilder is an interface for the EnergyPlus simulation engine, which is a qualified computer simulation software for calculating energy savings to improve energy efficiency [22]. It has a three dimensional interface that provides a real hourly weather data based simulation, which takes into consideration heat conduction and convection between different building zones and solar gain through external windows [23]. The accuracy of this software has been validated by BESTest (Building Energy Simulation Test) which is developed by the International Energy Agency [24]. Simulations were conducted during a full year from January to December. The HVAC System was assumed to be full air conditioned.

\section{Base-Case Residential Building}

Residential building's lands in Riyadh vary in depth and frontal elevation. In a study supported by Riyadh Development Authority (2006), the results showed that the average depth of a single residential land area is $30 \mathrm{~m}$, land area is $30 \mathrm{~m}$, the average frontal elevation is $20 \mathrm{~m}$, and the average area in Riyadh is $600 \mathrm{~m}^{2}$. For this study, the typical base-case housing unit was developed with physical characteristics illustrated in Table 1 . The building has a rectangular shape of $(25.6 \times 16) \mathrm{m}$ and composed of two floors and the third recessed floor which 
should not exceed $50 \%$ of the built area of the second floor according to Riyadh building regulations. Each floor has a height of $3.5 \mathrm{~m}$ and the total height of the two floors is $7 \mathrm{~m}$. Floor plans of the base case building are plotted in Figure 4 .

Physical characteristics of the prototype residential building is shown in Table 1 .

After assessing the thermal performance of the base-case building, the simulation results was compared to that of the performance of same building when being in the middle of several cases of urban block that have urban dimensions based on Riyadh building regulations as shown in Figure 5.

\section{The Study Parameters}

The study examined the impact of building regulations on the thermal performance and energy consumption of residential buildings. It investigated three main parametres which are:

- The ratio of building height to street width $(\mathrm{H} / \mathrm{W})$.

- Street orientation.

- The building orientation.

Table 1. Physical characteristics of the prototype residential building.

\begin{tabular}{|c|c|}
\hline & Base Case Building \\
\hline Location & $\begin{array}{c}\text { Riyadh }\left(24^{\circ} \mathrm{N} \text { Latitude, } 46^{\circ} \mathrm{E} \text { Longitude, and } 600 \mathrm{~m}\right. \\
\text { above sea level })\end{array}$ \\
\hline Number of floors & Two and the third recessed floor \\
\hline Ceiling height & $3.5 \mathrm{~m}$ \\
\hline Window to wall ratio & $12 \%$ \\
\hline Type of window glass & Single glazing \\
\hline Interior walls construction & Concrete block (200 mm). \\
\hline Exterior walls construction & Concrete block (200 mm). \\
\hline Interior walls finishes & Plaster $(20 \mathrm{~mm})$. \\
\hline Roof construction & Concrete roof slab \\
\hline
\end{tabular}

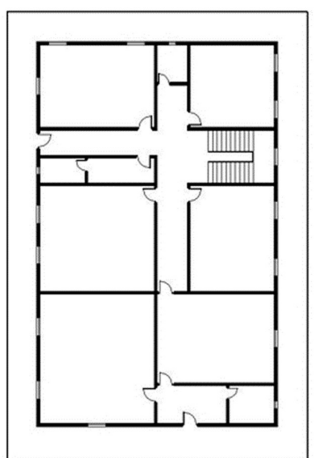

First Floor

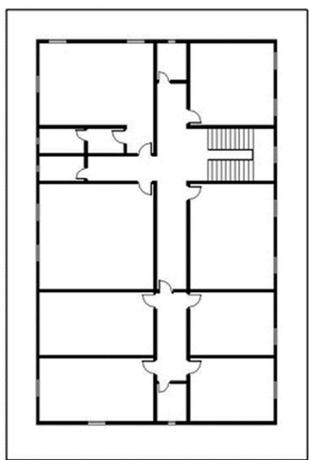

Second Floor

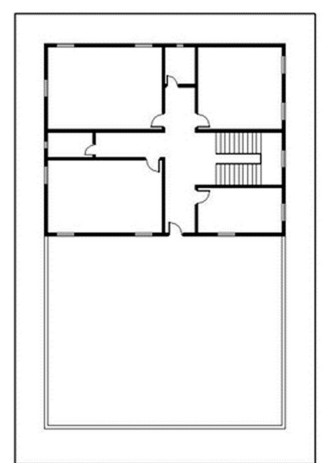

Third Floor

Figure 4. Floors plans of base case building. 


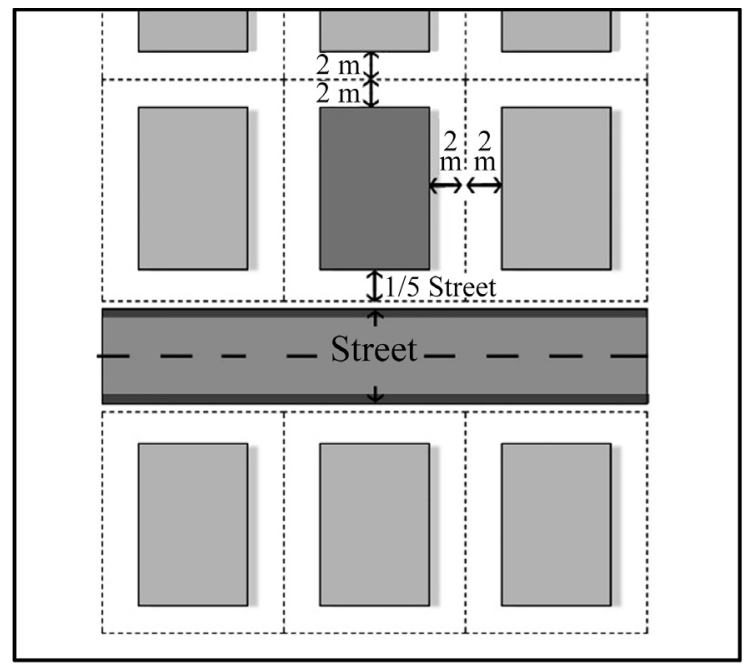

Figure 5. Urban dimensions based on Riyadh building regulation.

It should be noted that the ratio of building height to spacing between adjacent buildings (H/D) equals (1.87) in all simulation cases according to Riyadh building regulation which defined the minimum rear and side setback to not be less than $2 \mathrm{~m}$, and building height to not be more than two floors and the third recessed floor. The impacts of the mentioned parametres on building energy behavior and annual cooling loads were investigated. Energy simulation was performed on stand alone base-case and while in the middle of urban block. The study included the following four main street widths which represent the most common street widths in Riyadh: $12 \mathrm{~m}, 15 \mathrm{~m}, 20 \mathrm{~m}$, and $25 \mathrm{~m}$. According to the current building regulation of Riyadh, the rear and side setbacks should not be less than $2 \mathrm{~m}$, so it was assumed that the distance between adjacent buildings is 4 $\mathrm{m}$. In terms of the frontal setback, the building regulation stated that it should not be less than fifth of the width of the main street, so it was assumed that the distances between buildings located in the parallel sides of the street including street width and frontal setback are 16.8, 21, 28 and $35 \mathrm{~m}$, for the following values of street width 12, 15, 20 and $25 \mathrm{~m}$ respectively. The study included two basic street orientations, four building orientations and four different height to width ratios. Figure 6 shows the generic form of urban block along (E-W) street urban block, while " $D$ " stands for the summation of side setbacks, and " $H$ " stands for building height including $0.5 \mathrm{~m}$ for the parapet. The study examines sixteen alternatives of urban block, only the central building is considered in the simulation which is surrounded from each the north, south, west and east orientation.

According to the above assumptions, simulation analysis consists of the following cases: urban blocks with their street main axis running north to south, and urban blocks with their street main axis running east to west.

For each of the above synarios, the following H/W ratios are tested: 0.44, 0.35, 0.26 and 0.2 . Taking into account the four main building orientations, we come up with sixteen urban block alternatives which will be tested and compared with 
that of four synarios of reference building in case of being free standing and oriented to the four main orientations. Urban block configuration investigated in the study are shown in Table 2, which includes eight urban configurations in (North-South) street urban block and eight configurations in (East-West) street urban block, taking into account four building orientations.

The study examined annual cooling load, Incident solar radiation and hourly solar gain for the base-case building and the corresponding building within urban block. As a prelimnary simulation test, it was shown that the impact of the value $0.44 \mathrm{of}(\mathrm{H} / \mathrm{W})$ had the highest impact on the thermal performance of the building within urban block, with a slight difference in the impacts of the other values $(0.35,0.26 .0 .2)$. So, the value of $(\mathrm{H} / \mathrm{W}=0.44)$ was taken as a representative value in the statistical analysis.

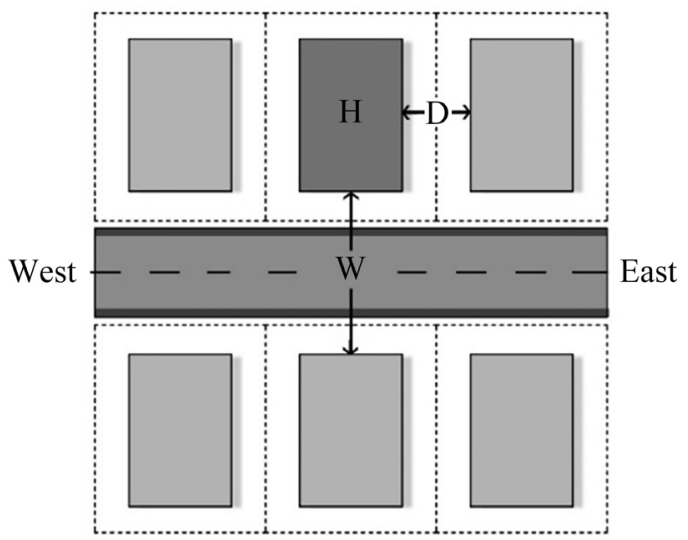

Figure 6. The generic form of the urban block.

Table 2. Urban block configuration investigated in the study.

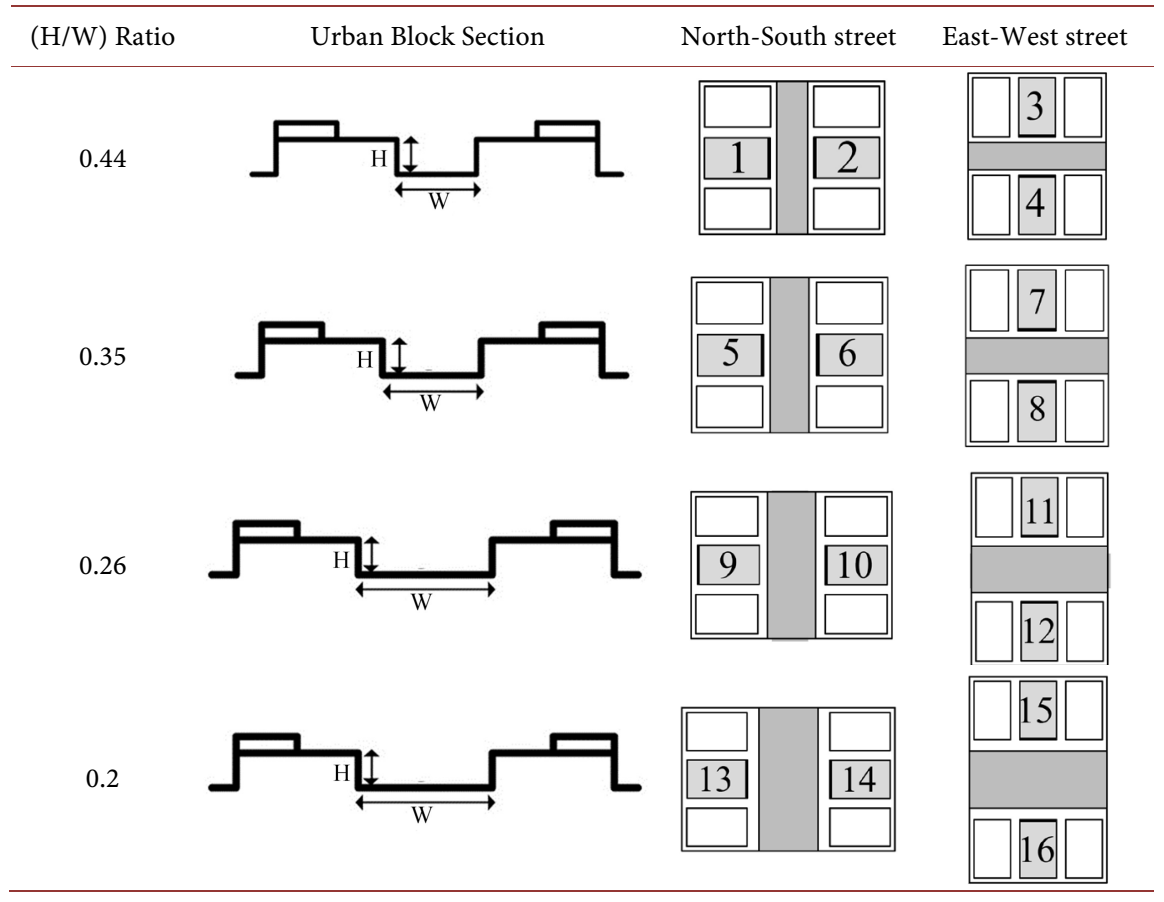




\section{Result Analysis}

The thermal performance of the free-standing base case building was first assessed, then its predicted performance was compared to the thermal performance of the same building within sixteen cases of the urban block to investigate the impact of adjacent buildings on the performance of the building.

\subsection{Evaluating the Thermal Performance of the Base-Case Building}

The thermal performance of the base-case of the free standing building was evaluated in case of facing the main four orientations: north, south, west and east by using the energy simulation tool. To evaluate the thermal performance of the building, an accurate hourly weather data is important to determine the solar heat gain received by the building. Therefore, an hourly weather file (epw) for Riyadh was imported from Energy Plus website and used as the weather data in the simulation. Because air conditioning is the main contributor for high energy consuming in residential buildings in Riyadh, the study mainly focuses on the evaluation of the cooling loads over the whole year. The simulation was run in the four main orientation: north, south, west and east, while the letters (B-N, B-W, B-S, B-E) was used to stand for the base-case stand alone building when being oriented to north, west, south and east respectively.

The simulation results showed that annual cooling load reached 64,267, 62,190, 64,240 and 62,187 kWh for (B-N), (B-W), (B-S) and (B-E) respectively. The results indicated that cooling load starts from $0 \mathrm{kWh}$ in all base-case synarios during winter months (January) up to approximately 14,319, 13,902, 14,321 and 13,906 $\mathrm{kWh}$ during the middle of the summer (August) in (B-N), (B-W), (B-S) and (B-E) respectively. July and August are the hottest months in Riyadh, as a result, the cooling load has increased significantly due to the high temperature values. On the other hand, January and February are the coldest months in Riyadh, with temperature ranges between $0^{\circ}$ to $20^{\circ}$. It can be noted that in case of (B-N) and (B-S), the potential of solar radiation is very high because the long east and west facades are directly exposed to the sun, and this explains why there is a significant increase in cooling loads especially in summer months in compared to $(B-W)$ and (B-E) where the long south and north facades are not exposed to the sun. Monthly cooling loads of (B-N), (B-W), (B-S) and (B-E) is shown in Figure 7.

The simulation results also indicated that the incident solar radiation for (B$\mathrm{N}$ ) and (B-S) reached 59,533 and 58,576 kWh respectively, which is comparatively higher than the amount of incident solar radiation received by $(\mathrm{B}-\mathrm{W})$ and (B-E) which reached 56,377 and 58,576 kWh respectively.

\subsection{Evaluating the Thermal Performance of the Building within Urban Block}

The same base-case building was evaluated by the same method of simulation 
within an urban block. About sixteen cases of urban block with four different street widths and two street direction (north-south, east-west) were modelled and simulated for cooling loads. A comparison of the annual cooling loads of the middle building and the corresponding base-case building was performed. The results of the simulation demonstrated that there is a significant impact of adjacent shadings on cooling loads as shown in Figure 8.

As mentioned before, the annual cooling load (B-N) when being free-standing without adjacent shading was $64,267 \mathrm{kWh}$, while when being in the middle of the (east-west) street urban block, with $\mathrm{H} / \mathrm{W}$ ratio of 0.44 equals $57,072 \mathrm{kWh}$. The difference in the annual cooling load is $7195 \mathrm{kWh}$, which represents a reduction of (11.2\%). It can be noted that there is a slight difference in the reduction when $\mathrm{H} / \mathrm{W}$ ratio ranges between $(0.44-0.2)$, because the reduction in cooling load is mainly caused by shading effects from the adjacent buildings located on the west and east side of the building which lead to a reduction of heat gain, thus, annual cooling load, while the effect of shading from buildings located on the opposite north side of the street is negligible, because the distance $\mathrm{W}$ is relatively longer than the distance D. Furthermore, the potential of incidence solar radiation on eastern and western facades is very high in comparison to the northern one. The results of the simulation showed that changing street orientation from east-west to north-south leads to a slight reduction in annual cooling load. The annual cooling load for (B-W) is $62,190 \mathrm{kWh}$, while that of the same building when being simulated in the middle of the north-south street urban block, with $\mathrm{H} / \mathrm{W}$ ratio of 0.44 is $58,769 \mathrm{kWh}$. The difference in annual cooling load is $3420 \mathrm{kWh}$, which represents a reduction of $5.5 \%$ as shown in Figure 9.

The results also indicated that there is a significant impact of adjacent shadings on the incident solar radiation. The difference in the internal gain of the north facing building within urban block with east-west street direction when $(\mathrm{H} / \mathrm{W}=0.44)$ reached $32,212 \mathrm{kWh}$, which represents a percentage reduction of $54 \%$. However, when changing street direction to north-south, the percentage reduction of incident solar radiation of the west-facing building reached 23,132 $\mathrm{kWh}$, which represents a percentage reduction of $41 \%$ as shown in Figure 10 . This explains why the reduction in annual cooling loads in urban block with east-west street is higher than that of north-south street.

Hourly solar heat gain was also investigated in the study. The difference in the amount of heat gain increases during the early and late hours of the day when the sun position has low latitude and the ability of adjacent buildings to block incident solar radiation become very high as shown in Figure 11 and Figure 12. Obviously, it can be noted that the reduction in hourly heat gain in (B-N) within urban block with east-west direction street is higher than that of (B-W) in urban block with north-south direction street, this is due to the adjacent shading effect of the east and west facades which receive more solar radiation than the southern and northern facades. 


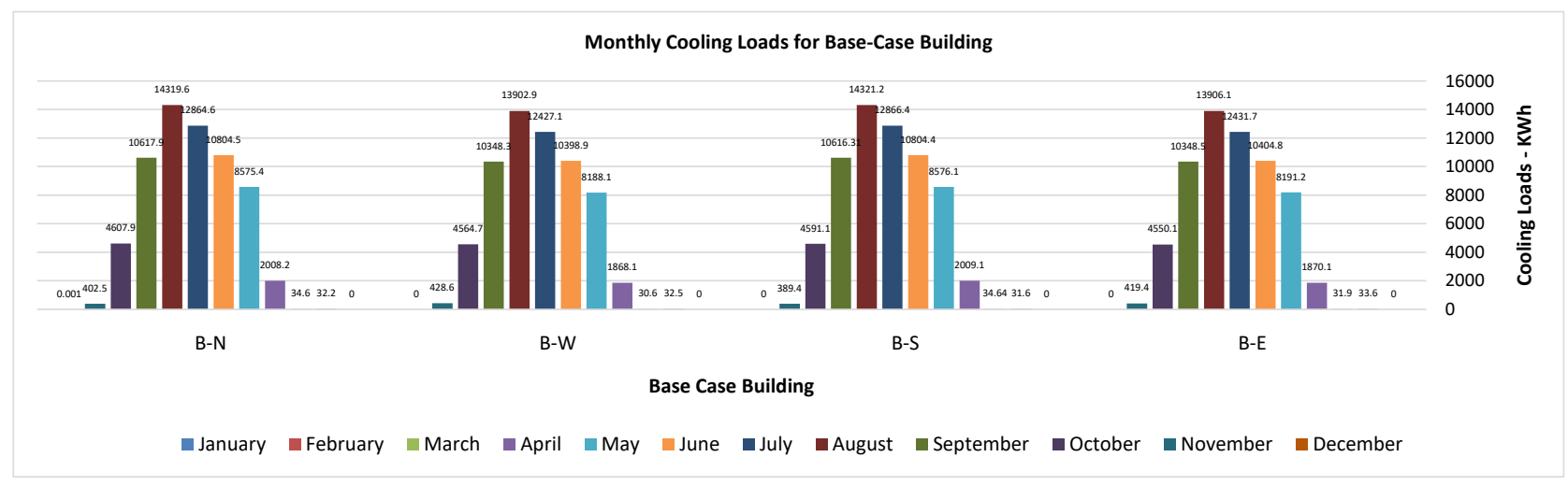

Figure 7. Monthly cooling loads for the base case building.

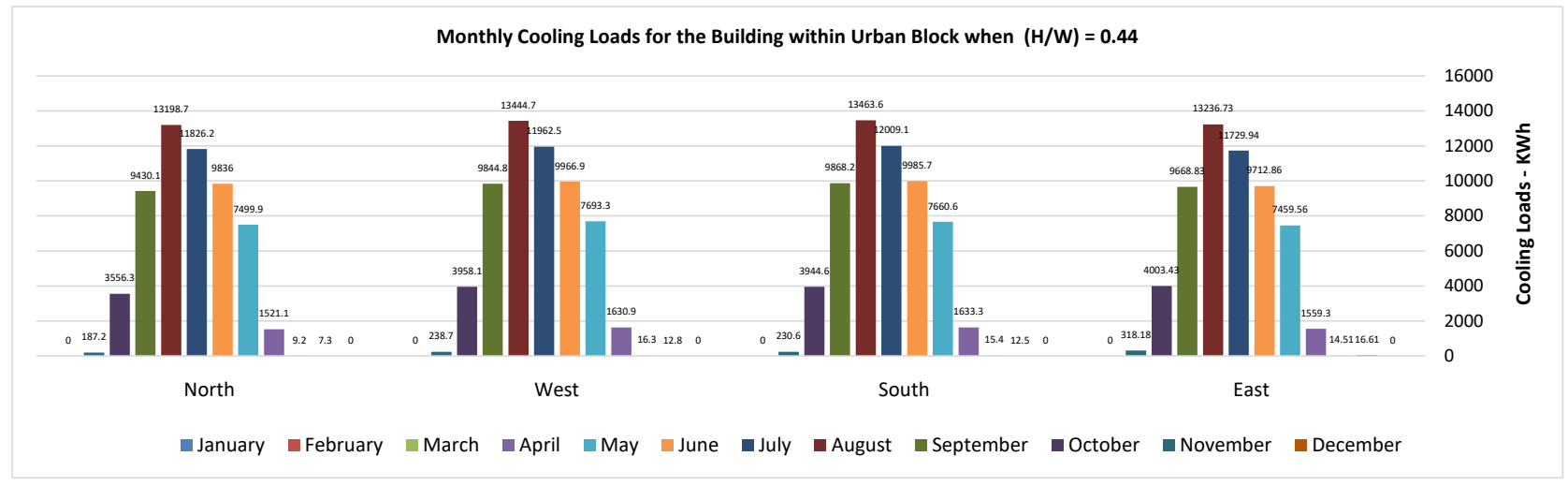

Figure 8. Monthly cooling loads for the building within urban block when $(\mathrm{H} / \mathrm{W})=0.44$.

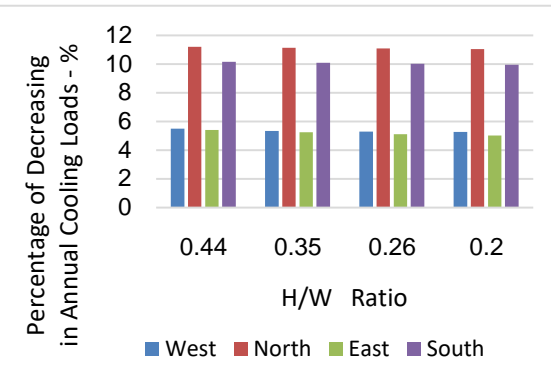

Figure 9. Percentage of decreasing in annual cooling load when compared to base case building.

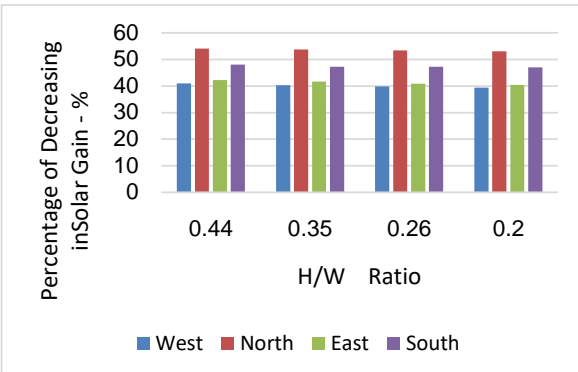

Figure 10. Percentage of reduction in solar heat gain when compared to base case building. 


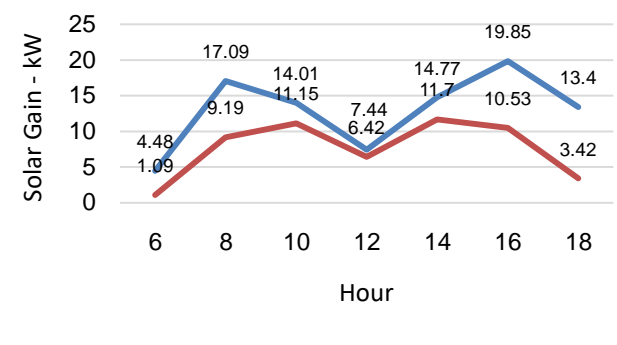

$-\mathrm{B}-\mathrm{N} \longrightarrow(($ North0.44 Within Urban Block $-\mathrm{H} / \mathrm{W}=$

Figure 11. A comparison of hourly solar gain of (B-N) and the north-facing building.

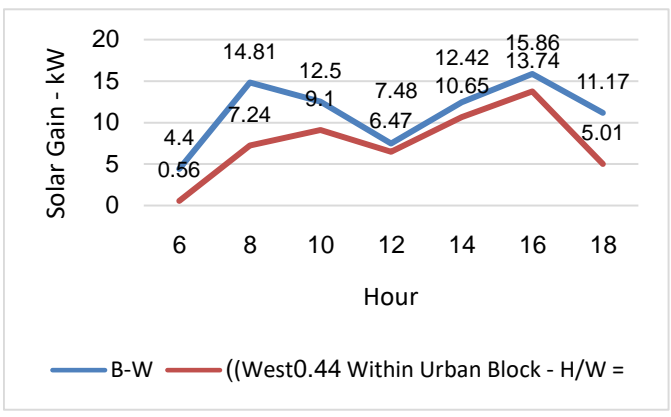

Figure 12. A comparison of hourly solar gain of (B$\mathrm{W})$ and the west-facing building.

\section{Evaluating the Modifications in Building Regulations}

In the previous simulation cases, urban dimensions were set according to Riyadh building regulation (As of 2018). This part of the study addresses the impacts of urban dimensions modification on the thermal performance of buildings. Two types of modification will be evaluated: height to adjacent building spacing ratio $(\mathrm{H} / \mathrm{D})$ and the height of west and north adjacent buildings.

\subsection{Evaluating the Effect of Building Height to Adjacent Building Spacing Ratio (H/D)}

According to 2018 Riyadh building regulations, the minimum side and rear setbacks should be $2 \mathrm{~m}$, resulting a H/D ratio of 1.87. In this part of the study, the following H/D ratios was examined, 0, 0.93 and 3.75 which represents the following values of distance between adjacent buildings (D): $0 \mathrm{~m}, 8 \mathrm{~m}$. and $2 \mathrm{~m}$ as shown in Figure 13.

The results of the simulation demonstrate that there is a significant impact on the building cooling load when the building is attached from two sides in a linear fabric $(H / D=0)$ as shown in Figure 14.

The results also indicated that the difference in annual cooling loads reached $17,699,11,934,16,828$ and 11,466 kWh for north, west, south and east building respectively. In urban block with east-west street, the percentage of reduction in annual cooling load of the north-facing building was $27.5 \%$, in comparison to the reduction percentage of $11.2 \%$ when $\mathrm{H} / \mathrm{D}$ ratio equals 1.87 . Buildings located 
adjacently to the east and west side of the north-facing building can offer a substantial reduction of solar heat gain and consequently a reduction of annual cooling load. However, in terms of urban block with north-south street, the results indicated that the reduction percentage in cooling loads of the west facing building was $19.1 \%$ in comparison to the reduction percentage of $5.5 \%$ when H/D ratio equals 1.87 as shown in Figure 15.

Under this situation, the incident solar radiation was affected significantly. The results indicated that the difference in incident solar radiation reached $48,761,38,440,42,162$ and $37,566 \mathrm{kWh}$ for north, west, south and east building respectively. The percentage of the reduction in incident solar radiation of the north facing building within urban block with east-west street, reached $81.9 \%$, while the reduction percentage of that when H/D ratio equals 1.87 was only $54.1 \%$. In case of urban block with north-south street, the percentage of reduction in incident solar radiation in the west facing building was $68.1 \%$ as shown in Figure 16.
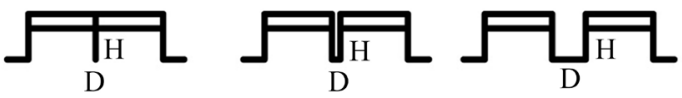

$$
\mathrm{H} / \mathrm{D}=0
$$

$\mathrm{H} / \mathrm{D}=3.75$

$\mathrm{H} / \mathrm{D}=0.93$

Figure 13. H/D Ratios investigated in the Study.

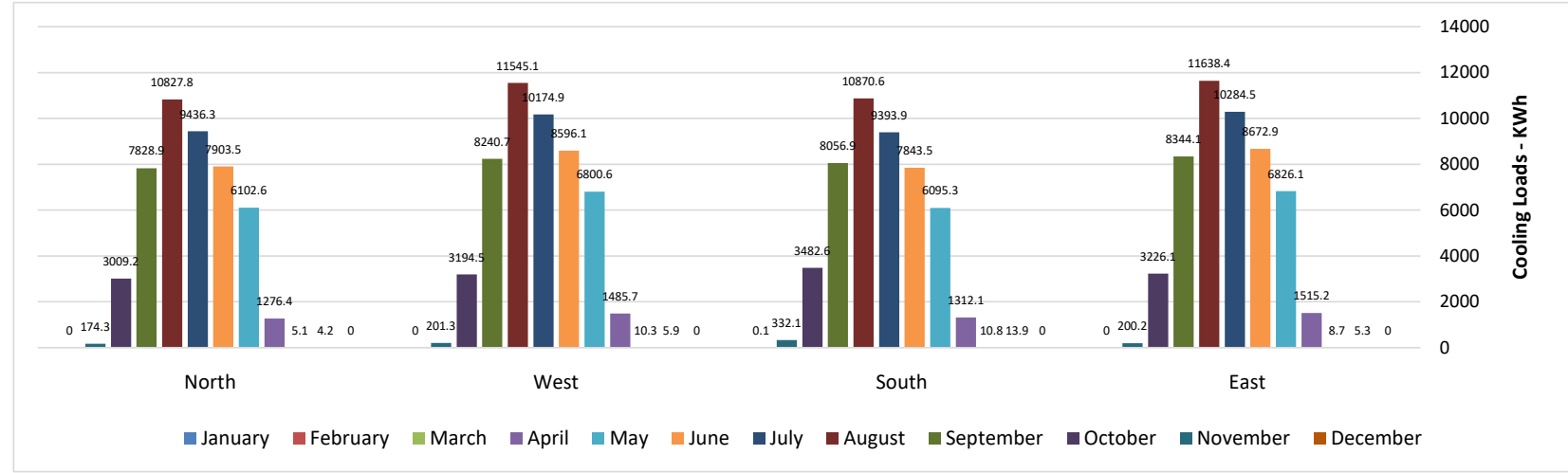

Figure 14. Monthly cooling loads for the building within urban block when $(H / D=0),(H / W=0.44)$.

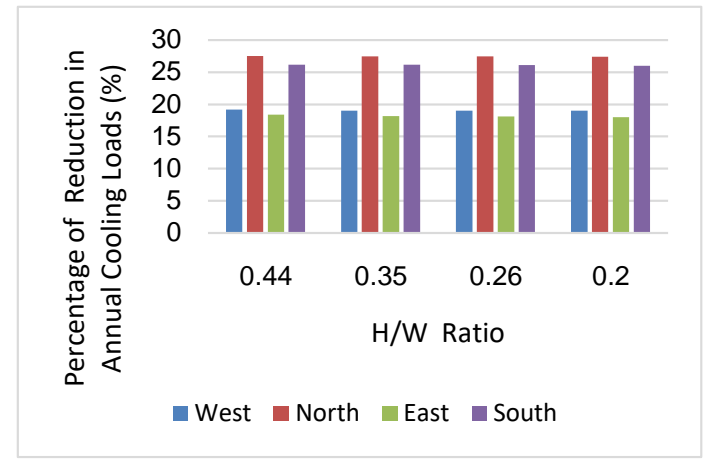

Figure 15. Percentage of reduction in annual cooling loads when $(\mathrm{H} / \mathrm{D}=0)$. 


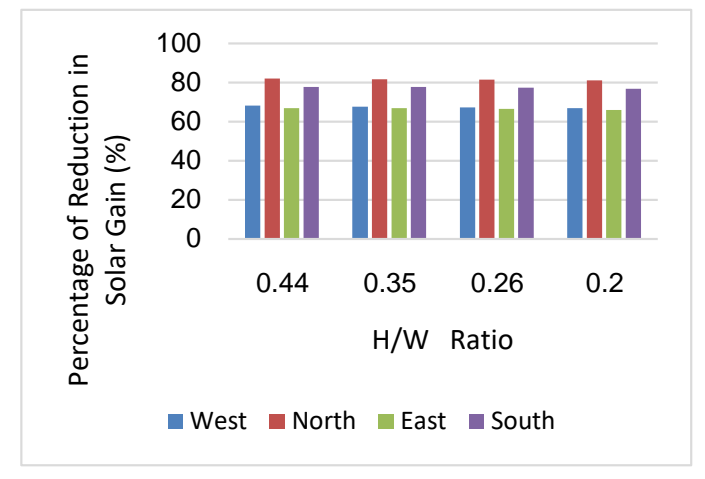

Figure 16. Percentage of decreasing in solar gain when $(H / D)=0$.

The results also indicated that there is a significance difference in the hourly solar heat gain of the building during the day hours. In urban block with eastwest street, the hourly solar heat gain of the north faced building was significantly reduced during the early and late hours of the day, where the sun position has low latitude and the ability of east and west adjacent buildings to block incident solar radiation become very high as shown in Figure 17. It can be noted that the reduction in hourly solar heat gain of the west facing building in urban block with north-south street, was less the that of the north-facing building, because east and west facades receive more solar radiation as shown in Figure 18.

Changing height to distance between adjacent building ratio (H/D) to 3.75 results in considerable changes in annual cooling loads and incident solar radiation as shown in Figure 19. The results indicated that the difference in annual cooling loads reached 4860, 9937, 8702 and $4719 \mathrm{kWh}$ for north, west, south and east building respectively.

The percentage of the reduction in annual cooling loads of the north facing building in the urban block with east-west street equal 15.4\%, while the reduction percentage of that when H/D ratio equals 1.87 was only $11.2 \%$. This is because buildings located to the east and west side of the building offer substantial shading of diffuse solar radiation leading to reduce the amount of heat gain. In terms of urban block with north-south street, the results indicated that the reduction percentage in cooling loads of the west facing building was $7.81 \%$ in comparison to the reduction percentage of $5.5 \%$ when $\mathrm{H} / \mathrm{D}$ ratio equals 1.87 as shown in Figure 20.

In terms of incident solar radiation, the results indicated that the difference in incident solar radiation reached 42,576, 30,177, 32,930 and 30,757 $\mathrm{kWh}$ for north, west, south and east building respectively. In urban block with east-west street, the percentage of the reduction in incident solar radiation of the north facing building reached $71.5 \%$, while the reduction percentage of that when H/D ratio equals 1.87 was only $54.1 \%$. In case of urban block with north-south street, the percentage of reduction in incident solar radiation in the west facing building was $53.5 \%$. 


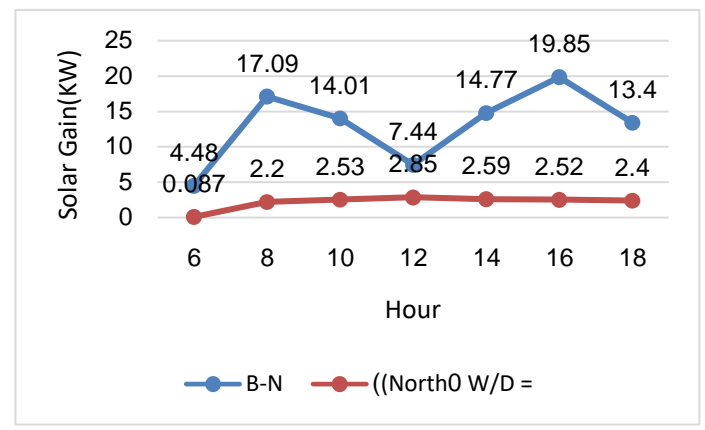

Figure 17. A comparison of hourly solar gain of (B-N) to the north-facing building when $(\mathrm{H} / \mathrm{W}=0.44),(\mathrm{H} / \mathrm{D}=0)$.

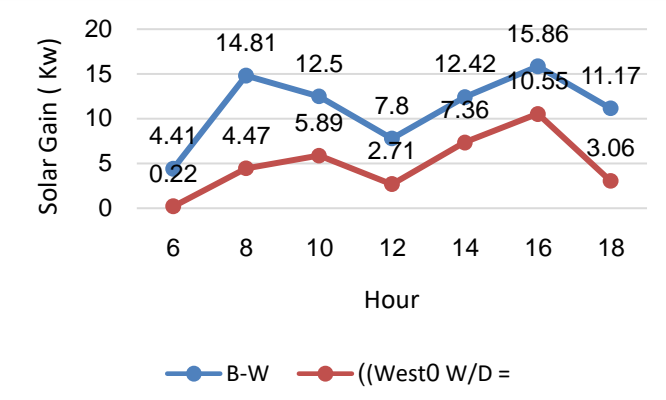

Figure 18. A comparison of hourly solar gain of $(\mathrm{B}-\mathrm{W})$ to the west-facing building when $(\mathrm{H} / \mathrm{W}=0.44),(\mathrm{H} / \mathrm{D}=0)$.

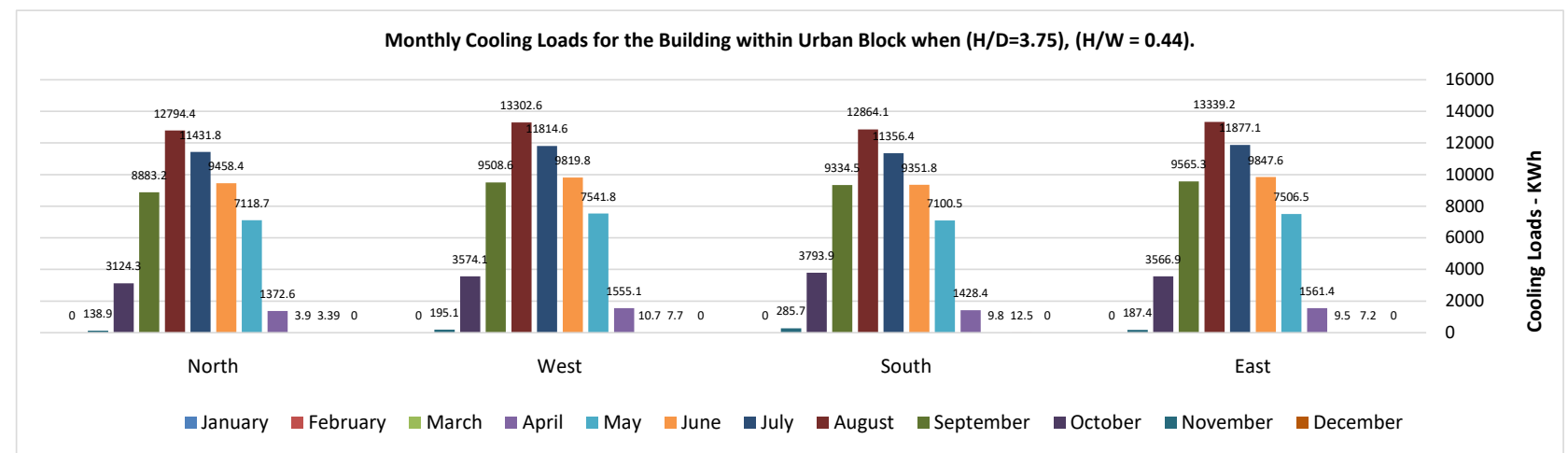

Figure 19. Monthly cooling loads for the building within urban block when $(\mathrm{H} / \mathrm{D}=3.75),(\mathrm{H} / \mathrm{W}=0.44)$.

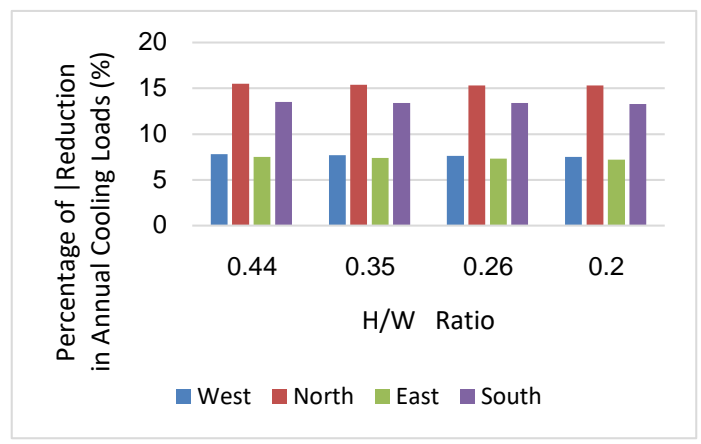

Figure 20. Percentage of reduction in annual cooling loads when $(\mathrm{H} / \mathrm{D}=3.75)$. 
Heat gain during day hours was also rescued when (H/D) ratio equals 3.75. A comparison of the hourly solar heat gain of the north facing building in the urban block with east-west street when H/D ratio equals 3.75, to the hourly solar heat gain of $(\mathrm{B}-\mathrm{N})$ is plotted in Figure 21. The results showed that the reduction of solar heat gain increases in the early and the late hours of the day. However, in case of the west facing building, the hourly heat gain was reduced significantly in the early hours of the day rather than the late hours as shown in Figure 22.

On the other hand, changing $H / D$ ratio to 0.93 had a negative impact on annual cooling loads and incident solar radiation in comparison to the ratio of 1.87. The difference in annual cooling loads of the building within urban block reached 4112, 2016, 3884 and $1941 \mathrm{kWh}$ for north, west, south and east building respectively in comparison to the corresponding base-case building. The percentage of the reduction in annual cooling loads of the north facing building in the urban block with east-west street reached only $6.3 \%$, however, this value is less than the reduction percentage of $(11.2 \%)$ when $H / D$ ratio equals 1.87 . This is due to the decreased amount of shadings casted by the buildings located to the east and west side of the building, and consequently the increased amount of heat gain. The pattern of reduction in annual cooling loads of the west facing building was similar to that of urban block with north-south street. The percentage of reduction in annual cooling loads of the west facing building in urban block with north-south street reached $3.2 \%$, in comparison to the percentage reduction of $5.5 \%$ when $H / D$ ratio equals 1.87 as shown in Figure 23.

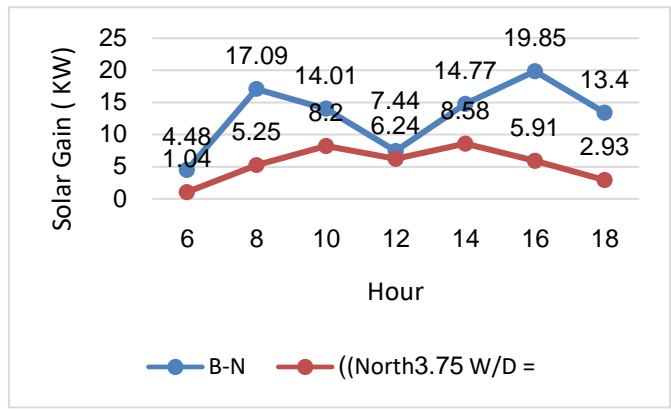

Figure 21. A comparison of hourly solar gain of $(\mathrm{B}-\mathrm{N})$ to the north-facing building when $(\mathrm{H} / \mathrm{W}=0.44),(\mathrm{H} / \mathrm{D}=3.75)$.

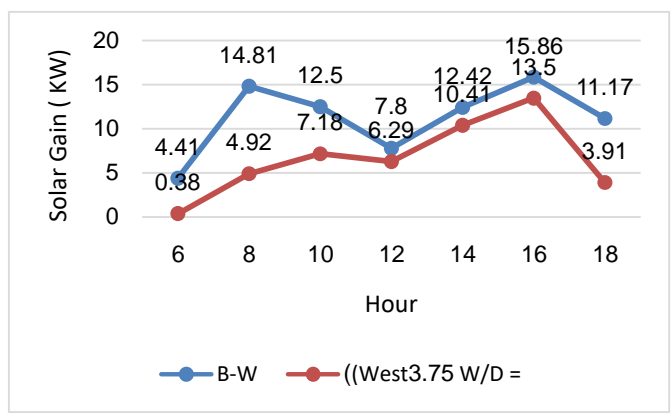

Figure 22. A comparison of hourly solar gain of $(\mathrm{B}-\mathrm{W})$ to the west-facing building when $(\mathrm{H} / \mathrm{W}=0.44),(\mathrm{H} / \mathrm{D}=3.75)$. 


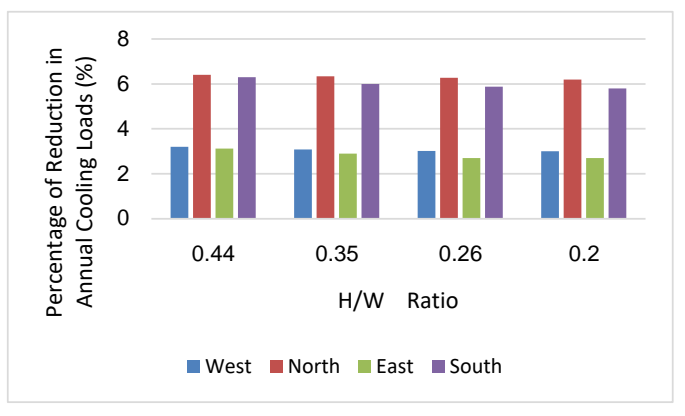

Figure 23. Percentage of decreasing in annual cooling loads when $(\mathrm{H} / \mathrm{D}=0.93)$.

The difference in incident solar radiation reached 19,433,13,742, 15,718 and $13,877 \mathrm{kWh}$ for north, west, south and east building respectively. The percentage of the reduction in incident solar radiation of the north facing building reached $32.6 \%$ in urban block with east-west street was, while the reduction percentage of that when H/D ratio equals 1.87 was $54.1 \%$. However, changing the street direction of the urban block to north-south direction resulted in a percentage reduction of $24.3 \%$ for the west facing building.

The hourly solar heat gain of the building was also affected negatively during the early and late hours of the day when H/D ratio equal 0.93 in comparison to the impact of the ratio 1.87, as shown in Figure 24 and Figure 25. This is basically due to the increased potential of incidence solar radiation received by all building facades.

With the above in mind, a comparison of the percentage reduction of annual cooling loads in urban block with the following simulated H/D ratios: $0,3.75$ and 0.93 to the percentage reduction of the north building when H/D ratio equals 1.87 is plotted in Figure 26. The value of H/D = 1.87 represents Riyadh building regulation. The results indicated that there is a negative impact on the cooling loads when H/D ratio equals 0.93 .

\subsection{Evaluating the Effect of Changing the Height of Adjacent Buildings}

The number of building floors allowed by Riyadh building regulations is two floors and the third recessed floor which results in urban blocks with uniform buildings heights. In this part of the study, the thermal performance of the building was evaluated when changing the height and number of floors of adjacent buildings. Two cases was included in the study, the first case is changing the height of the western adjacent building to 4 floors in case of urban block with east-west street, while the second phase is changing the height of the southern adjacent building to 4 floors in case of urban block with north-south street. In urban block with east-west street and four-floor western adjacent building, the simulation results indicated that the reduction of annual cooling load of the north facing building reached $13.5 \%$, while the reduction of that when the western adjacent building has two floors was only $11.2 \%$. It is noted that the pattern of reduction in annual cooling load in urban block with north-south street, and 
four-floor northern adjacent building is similar to that of urban block with east-west street. The simulation results indicated that the percentage reduction of annual cooling load of the west facing building when the southern adjacent building has four floors reached $6.7 \%$ while the reduction of that when the southern adjacent building has two floors was 5.5\%.

A comparison of the hourly solar heat gain of the north facing building in the urban block with east-west street when the western building has four floors, to the hourly solar heat gain of (B-N) is plotted in Figure 27. Solar radiation that is blocked by the four floor west adjacent building made a considerable reduction in the heat gain especially in the late hours of the day. Figure 28 shows a comparison of the west facing building in the urban block with north-south street when the southern building has four floors, to the hourly solar heat gain of (B-W).

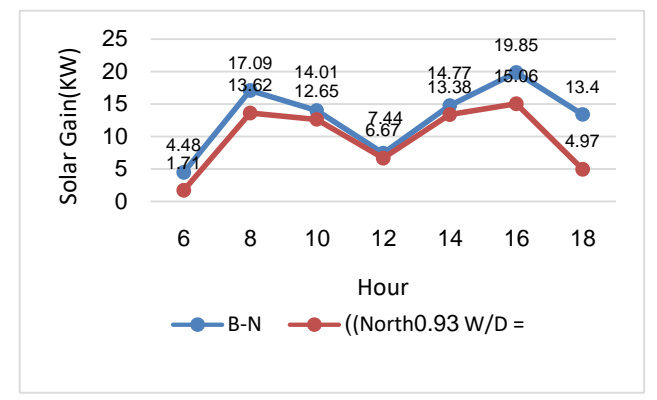

Figure 24. A comparison of hourly solar gain of $(\mathrm{B}-\mathrm{N})$ to the north-facing building when $(\mathrm{H} / \mathrm{W}=0.44),(\mathrm{H} / \mathrm{D}=0.93)$.

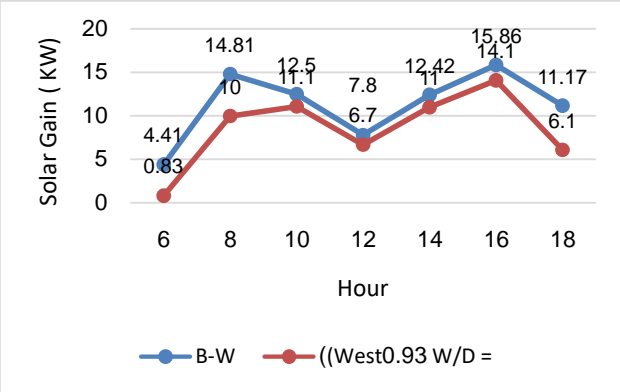

Figure 25. A comparison of hourly solar gain of $(\mathrm{B}-\mathrm{W})$ to the west-facing building when $(\mathrm{H} / \mathrm{W}=0.44),(\mathrm{H} / \mathrm{D}=0.93)$.

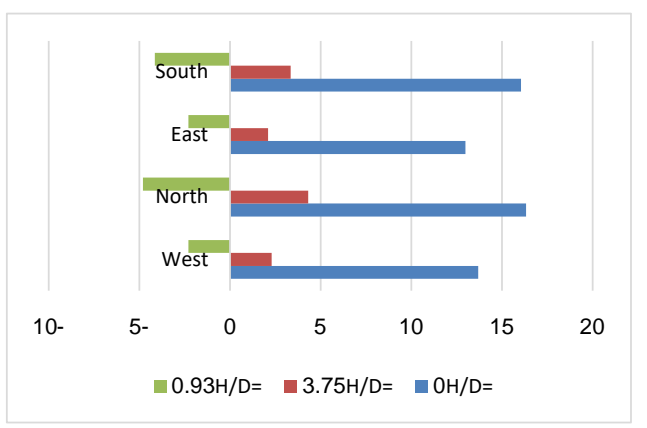

Figure 26. Percentage comparison of the reduction in annual cooling load for different $H / D$ ratios. Note that the Ratio of $(H / D)=1.87$ represents $0 \%$. 


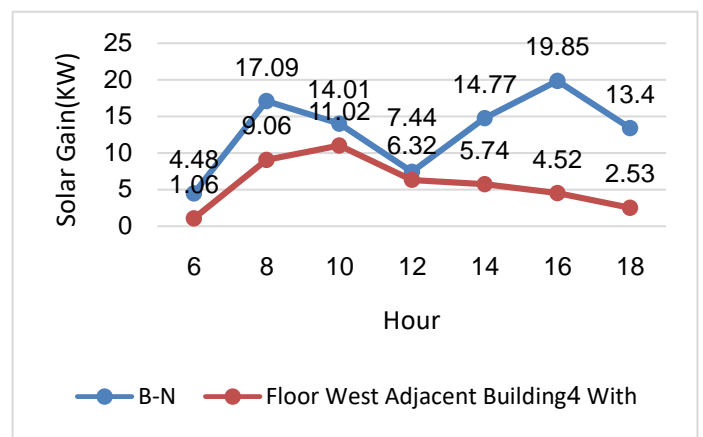

Figure 27. A comparison of hourly solar gain of (B-N) to the north-facing building when the western adjacent building has 4 floors and $(\mathrm{H} / \mathrm{W}=0.44)$.

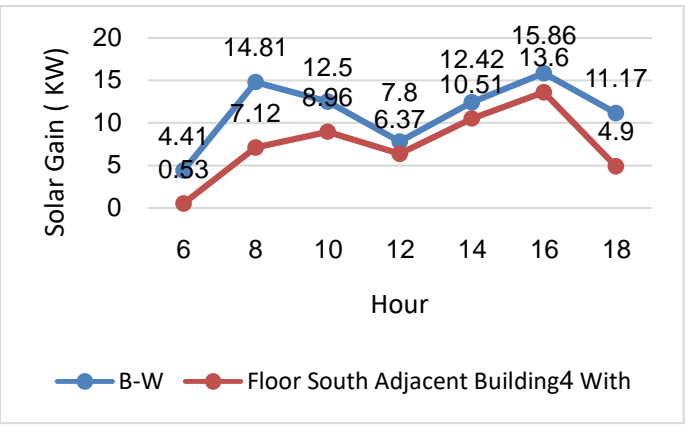

Figure 28. A comparison of hourly solar gain of (B-W) to the westfacing building when the southern adjacent building has 4 floors.

\section{Conclusion}

This study was undertaken to gain better understanding of energy demand in residential buildings in hot and dry climates by addressing the influence of building regulations on the energy behaviour of buildings in Riyadh. Energy simulation of a base case building was performed under the climatic condition of Riyadh. The results showed that the impacts of the current building regulations (as of 2018) on the thermal performance of residential buildings differ across the evaluated cases. The ratio of building height to street width, urban block street orientation, and building orientation are the main factors affecting thermal performance of buildings within urban block. The results indicated that the ratio of building height to street width had a slight impact on the cooling loads due to the long distance between opposite buildings. For the aim of investigating the impacts of building regulations in improving thermal performance of buildings, the study further assessed the impacts of urban dimensions modification on the thermal performance of buildings. Adjusting the ratio of building height to the distance between buildings was the main factor that made a significant impact in reducing cooling loads. In comparison to the current building regulation of Riyadh, the adopted urban dimensions were able to significantly improve the indoor conditions, reduce the heat gain from solar radiation and consequently reduce cooling load. The simulation analysis offers the potential for major savings in energy consumption for cooling purposes of residential buildings in Saudi Ara- 
bia. The reduction of energy consumption is based on few planning principles that could have a significant impact on the energy behaviour of buildings. To improve thermal performance of residential buildings, it is vital to move towards taking consideration to environmental aspects in building regulations to come up with compatible building regulations with hot, dry climate of Riyadh. Further study could be done to test the impacts of the new building regulation which will be introduced in Saudi Arabia in 2020. The findings of this paper are not only limited to residential buildings in Riyadh, but they can be applied to any buildings in hot arid climate.

\section{Acknowledgements}

The authors of this paper would like to thank the Deanship of Scientific Research at King Saud University and the Research Center at the College of Architecture and Planning for supporting this research.

\section{Conflicts of Interest}

The authors declare no conflicts of interest regarding the publication of this paper.

\section{References}

[1] Berardi, U. (2015) Building Energy Consumption in US, EU, and BRIC Countries. Journal of Procedia Engineering, 118, 128-136. https://doi.org/10.1016/j.proeng.2015.08.411

[2] Al-Hadhrami, L.M. and Ahmad, A. (2009) Assessment of Thermal Performance of Different Types of Masonry Bricks Used in Saudi Arabia. Journal of Applied Thermal Engineering, 29, 1123-1130. https://doi.org/10.1016/j.applthermaleng.2008.06.003

[3] Krarti, M., Dubey, K. and Howarth, N. (2017) Evaluation of Building Energy Efficiency Investment Options for the Kingdom of Saudi Arabia. Journal of Energy, 134, 595-610. https://doi.org/10.1016/j.energy.2017.05.084

[4] SEC (2011) Saudi Electricity Company-Annual Report. Riyadh.

[5] Jubran, A. and Peter, B. (2019) Reducing High Energy Demand Associated with Air-Conditioning Needs in Saudi Arabia. Journal of Energies, 12, 87. https://doi.org/10.3390/en12010087

[6] Taleb, H.M. and Sharples, S. (2011) Developing Sustainable Residential Buildings in Saudi Arabia: A Case Study. Journal of Applied Energy, 88, 383-391. https://doi.org/10.1016/j.apenergy.2010.07.029

[7] Dastbaz, M., Gorse, C. and Moncaster, A. (2017) Building Information Modelling, Building Performance, Design and Smart Construction. Springer, Berlin, 1-326. https://doi.org/10.1007/978-3-319-50346-2

[8] UN, United Nations (2015) Paris Agreement.

[9] SEEK (2017) Saudi Energy Efficiency Centre. Annual Report.

[10] RDA, Riyadh Development Authority (2016) Background of the Riyadh Public Transport Network.

[11] MMRA, Ministry of Municipality and Rural Affairs (2019) Saudi Cities Report 
2019. Riyadh.

[12] Al-Hemiddi, N.A. and Megren Al-Saud, K.A. (2001) The Effect of a Ventilated Interior Courtyard on the Thermal Performance of a House in a Hot-Arid Region. Journal of Renewable Energy, 24, 581-595.

https://doi.org/10.1016/S0960-1481(01)00045-3

[13] Al-Ghamdi, S.A. and Alshaibani, K.A. (2018) The Potential of Solar Energy in Saudi Arabia: The Residential Sector. Journal of Engineering and Architecture, 6, 32-53. https://doi.org/10.15640/jea.v5n2a4

[14] MOI, Ministry of Information (2003) The Kingdom of Saudi Arabia Development. Riyadh.

[15] Facey, W. (1992) Riyadh: The Old City. London.

[16] Al-Hathloul, S. (2017) Riyadh Development Plans in the Past Fifty Years (19672016). Journal of Current Urban Studies, 5, 97-120. https://doi.org/10.4236/cus.2017.51007

[17] Philpy, J. (1959) Riyadh, Ancient and Modern. Middle East Journal, 35, 129-142.

[18] Doxiadis (1972) Riyadh Master Plan.

[19] Al-Hathloul, S. (1996) The Arab-Muslim City: Tradition, Continuity and Change in the Physical Environment. Dar Al Sahan, Riyadh.

[20] Al-Said, F. (2003) The Pattern of Structural Transformation of the Saudi Contemporary Neighbourhood: The Case of Al-Malaz, Riyadh, Saudi Arabia. 39th ISOCARP Congress, Cairo, 17-22 October 2003, 1-10.

http://www.isocarp.net/Data/case studies/347.pdf

[21] Alaidroos, A. and Krarti, M. (2015) Optimal Design of Residential Building Envelope Systems in the Kingdom of Saudi Arabia. Journal of Energy and Buildings, 86, 104117. https://doi.org/10.1016/j.enbuild.2014.09.083

[22] Mahgoub, M. (2015) Assessment of Thermal and Visual Micro-Climate of a Traditional Commercial Street in a Hot Arid Climate. Newcastle University, Newcastle upon Tyne.

[23] Chowdhury, A.A., Rasul, M.G. and Khan, M.M.K. (2008) Thermal-Comfort Analysis and Simulation for Various Low-Energy Cooling-Technologies Applied to an Office Building in a Subtropical Climate. Journal of Applied Energy, 85, 449-462. https://doi.org/10.1016/j.apenergy.2007.10.001

[24] Radhi, H. (2010) On the Optimal Selection of Wall Cladding System to Reduce Direct and Indirect $\mathrm{CO}_{2}$ Emissions. Journal of Energy, 35, 1412-1424.

https://doi.org/10.1016/j.energy.2009.11.026 